\title{
INACCURATE REALIZATION OF MASORETIC ANNOTATIONS \\ FROM LENINGRAD CODEX B19A TO THE BIBLIA HEBRAICA SERIES: \\ GENERAL REMARKS ${ }^{1}$
}

Edson de Faria Francisco ${ }^{2}$

\section{Resumo}

Neste artigo são apresentadas e analisadas algumas situações de reprodução inexata de anotações massoréticas do Códice de Leningrado B19a (L) na série Biblia Hebraica (a Biblia Hebraica $[$ BHK], a Biblia Hebraica Stuttgartensia $[B H S]$ e a Biblia Hebraica Quinta $[B H Q])$, publicada pela Deutsche Bibelgesellschaft, de Stuttgart, na Alemanha. Além de tais obras, neste artigo são apresentas e analisadas, também, situações de reprodução inexata de anotações da masora magna do Códice L na obra Massorah Gedolah iuxta Codicem Leningradensem B19a, publicada pelo Pontificium Institutum Biblicum, de Roma, na Itália. A $B H K$, a $B H S$, a $B H Q$ e a Massorah Gedolah são publicações acadêmicas baseadas no Códice L, e cada uma à sua maneira, procura ser fiel ao referido manuscrito massorético. No presente artigo são identificas situações de inexatidão e são propostas possíveis correções, tendo por base a edição fac-símile do Códice L. Uma das questões abordadas neste artigo é que o estudo da massorá é de fundamental importância para os estudos bíblicos atuais e a reprodução das anotações elaboradas pelos massoretas no período medieval devem ser, na medida do possível, fielmente reproduzidas em edições impressas modernas.

Palavras-chave: Massorá, Bíblia Hebraica, série Biblia Hebraica, Códice de Leningrado B19a, massoretas.

\footnotetext{
1 This article was presented originally as lecture in the 25th Congress of the International Organization for Masoretic Studies (IOMS) at Ludwig-Maximilians University, Munich, Germany, on August 5-6, 2013. Original title of the lecture: "Mistaken Realization of Masoretic Annotations from Leningrad Codex B19a to the Biblia Hebraica series: General Remarks".

2 Methodist University of São Paulo (UMESP). Professor of Biblical Hebrew and Biblical Greek disciplines at the Faculty of Theology.
} 


\begin{abstract}
In this article are presented and analyzed some situations of inaccurate realization of masoretic annotations of Leningrad Codex B19a (L) in the Biblia Hebraica series (the Biblia Hebraica $[B H K]$, the Biblia Hebraica Stuttgartensia $[B H S]$ and the Biblia Hebraica Quinta $[B H Q])$, published by Deutsche Bibelgesellschaft, Stuttgart, Germany. Besides these works, in this article are presented and analyzed, likewise, situations of inaccurate realization of annotation from masora magna of the Codex L in the Massorah Gedolah iuxta Codicem Leningradensem B19a, published by Pontificium Institutum Biblicum, Roma, Italy. The $B H K$, the $B H S$, the $B H Q$ and the Massorah Gedolah are academic publications based on the Codex L, and each one aiming at being faithful to the masoretic manuscript. In this article are identified situations of inaccuracy and possible corrections are proposed, based on the facsimile edition of Codex L. One of the issues addressed in this article is that the study of the Masorah is of fundamental importance for the current Bible studies and the reproduction of the notes prepared by the masoretes in the medieval period shall be, insofar as possible, faithfully reproduced in modern printed editions.
\end{abstract}

Keywords: Masorah, Hebrew Bible, Biblia Hebraica series, Leningrad Codex B19a, masoretes.

Since the publication of the Biblia Hebraica $(B H K)$ (1929-1937), the annotations of the masora parva ( $\mathrm{mp})$ and masora magna $(\mathrm{mm})$ of the Leningrad Codex: Firkowitch I. B19a or Codex EBP. I B19a (L) (c. 1008-1009) ${ }^{3}$ have been realized, wholly or partially, in the Biblia Hebraica series. The BHK realizes only the masora parva and the Biblia Hebraica Stuttgartensia $(B H S)$ (1967-1977) realizes the masora parva, but in corrected and normalized realization and the masora magna in a separate volume, the Massorah Gedolah iuxta Codicem Lenin-

\footnotetext{
3 Since 1863 this masoretic manuscript belongs to the current Russian National Library (former SaltykovShchedrin State Public Library in Leningrad) in St. Petersburg, Russia. BEIT-ARIÉ, SIRAT, GLATZER, 1997, p. 114; SIRAT, 2002, p. 140; DUKAN, 2006, p. 247-248.
} 
gradensem B19a, in corrected and normalized realization too. Currently, the Biblia Hebraica Quinta (BHQ) (2004-) reproduces both the masora parva and the masora magna of the Codex L, in an essentially diplomatic representation, aiming at being faithful to its source. However, one can see that not always the Masorah realization of the Codex L has been carried out accurately, and errors, omissions, additions, modifications and erroneous deciphering can be found in the three editions of the Biblia Hebraica series and also in the Massorah Gedolah. Not always these works reflect what is actually in the Masorah of the Codex L.

This brief study intends to comment and to show, through selected examples, terms, expressions and masoretic notes reproduced erroneously in the $B H K, B H S$ and $B H Q$. The lecture will point at the possible causes of such inaccuracies and comment on possible corrections. In addition to the three editions, the lecture will address the Massorah Gedolah and several cases of inaccuracies that are found in it too. The lecture completes the topic "Reprodução Inexata de Anotações Massoréticas” (“Inaccurate Realization of Masoretic Annotations") of the chapter "Códice de Leningrado: Firkowitch I: B19a" ("Leningrad Codex: Firkowitch I: B19a") from the future publication Lexicon Masoreticum: Léxico de Terminologia Massorética Tiberiense. The Lexicon Masoreticum is the postdoctoral work by this author to the University of São Paulo (USP), to be published in the future.

Some situations of inaccuracies were chosen to this lecture from $B H K, B H S, B H Q$ and also from Massorah Gedolah. In this lecture were chosen sixteen situations: four from $B H K$, four from $B H S$, five from $B H Q$ and three from Massorah Gedolah.

\section{Biblia Hebraica (BHK)}

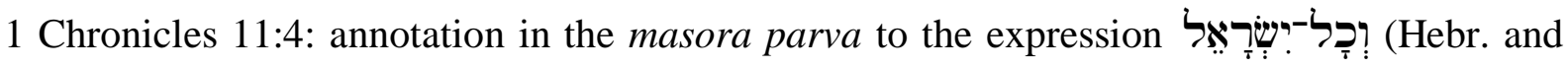
all Israel). 
Codex L: לד באפע פסוק וכל רץ פסוק דכות ) לד expression appears] thirty-four times in the middle of the verse, and it always has this same form when it stands at the beginning of the verse). ${ }^{4}$

BHK: לخ באמל פס וכל רא פסוק דכות ) לthe expression appears] thirty-four times in the middle of the verse, and it always has this same form when it stands at the beginning of the verse).

In the $B H K$ this masoretic annotation is almost identical to its source, but there are some textual differences: in the Codex L the masoretic expression middle of a verse) is abbreviated as באמשע פסוק, but in the BHK the same expression is abbreviated as באממע פס (in the Codex L the dot is above of the letter mēm [ن்] of the first term, but is

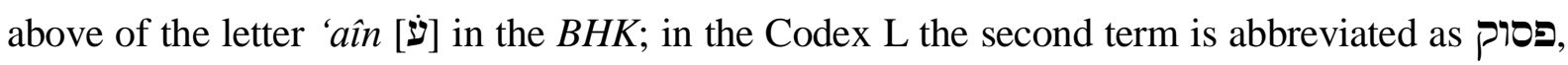

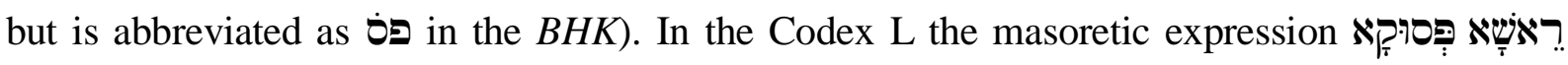
(Aram. the beginning of a verse) is abbreviated as רסוק, but in the $B H K$ the same expres-

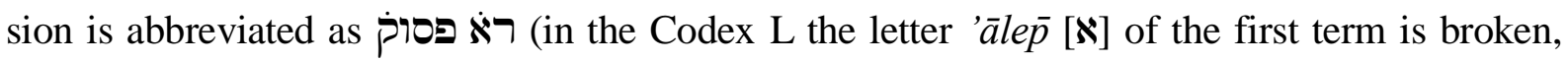
but the same letter has a dot in the $B H K$; in the Codex L the second term is abbreviated as and no dot, but the same term is abbreviated as פסוק with dot above of the letter qôp [ק] in the $B H K)$.

The BHS has another note with corrections:

BHS: לל ([the expression appears] thirty-five times).

Job 34:13: note in the masora parva to the expression (Hebr. and who).

\footnotetext{
4 The correct number is thirty-five times: Deut $21: 21$; Jos $3: 17 ; 7: 24 ; 8: 15 ; 8: 21 ; 10: 15 ; 10: 29 ; 10: 31 ; 10: 34$; 10:36; 10:38; 10:43; 1 Sam 17:11; 2 Sam 4:1; 3:37; 18:17; 1 Kgs 8:62; 8:65; 11:16; 15:27; 16:17; 2 Kgs 5:14; Ezra 2:70; 8:25; 10:5; Neh 7:73; 1 Chr 11:4; 13:6; 13:8; 2 Chr 7:6; 7:8; 10:3; 12:1; 13:4; 13:15. GINSBURG, 1971, vol. 2, letter $\supset$, § 250, p. 40; EVEN-SHOSHAN, 1997, p. 539.
} 
Codex L: לג פסוקין איתיהון ראש פסוק מי וג מילין רביע ומי ומינינה ז מלין (three verses which have in them, in the first part of the verse, the word [Hebr. who], and after there are three words and the forth word is the expression [Hebr. and who], and the number is eight words [i.e. there are eight words in the verse]). ${ }^{5}$

$B H K$ : no annotation.

This extensive masoretic annotation of the Codex $\mathrm{L}$ is missing in the $B H K$. However, in the $B H S$ the same annotation is realized, but in altered form to make easy the understanding (in the Codex L the masoretic note has prolix writing):

BHS: ג' ר״״פ פי וג מילין רביע ומי וכל פסוק דאית בהון ז מילין (three times in the first part of the verse appears the word [Hebr. who], and after there are three words and the forth word is the expression [Hebr. and who], and in the whole verse there are eight words).

Daniel 5.1: note in the masora parva to the word לח? (Aram. feast) vocalized with the vocalic signals šawā' (†) and segôl (†) and accentuated with the conjunctive accent munnah (अ).

Codex L: munnah). ${ }^{6}$

$B H K: \stackrel{\zeta}{:}($ ?) (unique with the vocalic signals šawā' and segôl [?]).

In the Codex L this masoretic note has four components: the term לית (Aram. unique [hapax legomenon]) abbreviated as ל, the vocalic signals šow $\bar{a}^{\prime}($ !) and segôl (†) and the conjunctive accent munnah (]). In the BHK the annotation has three components: the term

5 Ps 24:3; Job 34:13; 36:23. WEIL, 2001, § 3552, p. 387; EVEN-SHOSHAN, 1997, p. 649.

6 EVEN-SHOSHAN, 1997, p. 597. 
(Aram. unique [hapax legomenon]) abbreviated as $\zeta$ and the vocalic signals šawā' and segôl (the conjunctive accent munnah is missing). Moreover, the same note in the $B H K$ is almost uncleanliness. In the $B H S$ the same annotation is realized, but in simplified form to make easy the understanding:

BHS: 广 (unique).

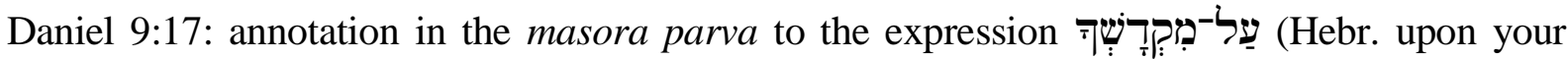
sanctuary).

Codex L: למרj אל מקדשך (according to the Babylonian masoretes the expression is written

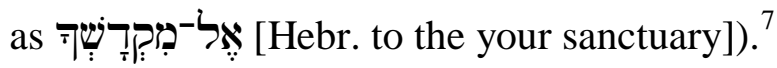

BHK: no annotation.

This masoretic annotation of the Codex $\mathrm{L}$ is missing in the $B H K$. Observation: there is a note in the upper critical apparatus of the $B H K$ that refers to the masoretic annotation of the

Codex L: Or אֶל (second to the Eastern [Babylonian] masoretic tradition the word is [Hebr. to]). However, in the $B H S$ there is a different annotation:

BHS: ì (three times). ${ }^{8}$

Images: Codex L and $B H K$

Codex L

$1 \mathrm{Chr} 11: 4(\mathrm{mp})$

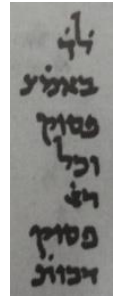

BHK

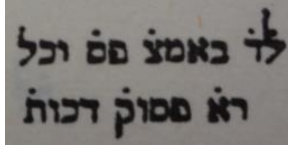

7 GINSBURG, 1971, vol. 1, letter $\pi$, § 638, p. 598.

8 WEIL, 2001, § 2759, p. 307. 
Job 34:13 (mp)

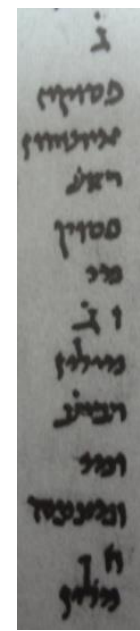

no annotation

Dan 5:1 (mp)
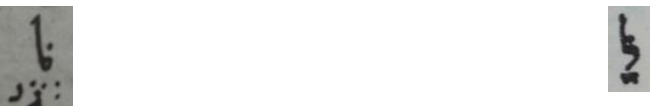

Dan 9:17 (mp)

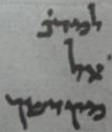

no annotation

\section{Biblia Hebraica Stuttgartensia (BHS)}

Genesis 24:7: note in the masora parva to the expression לִכְנִֶ (Hebr. ahead of you).

Codex L: ה וכל יחזק ונקי ذ מן (five times, and in all book of Ezekiel there is a feminine form, except for six occurrences) (sic). ${ }^{9}$

BHS: no annotation.

This masoretic annotation of the Codex L is missing in the $B H S$. However, in the $B H K$ the same annotation is reproduced in almost identical form:

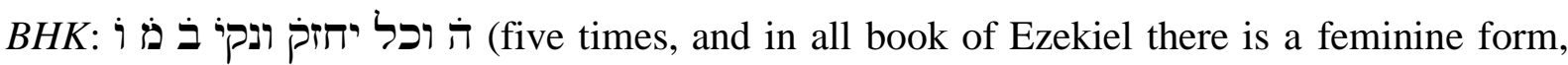
except for six occurrences) (sic).

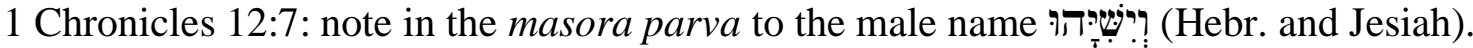

9 This masoretic note is very prolix, confused and, probably, is corrupted. The expression

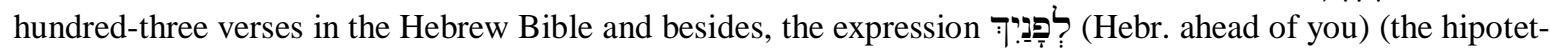
ical feminine form) is not found in the biblical Hebrew text. EVEN-SHOSHAN, 1997, p. 605. 
Codex L: בן נפתלי רִיִשִׁיָיהו (according to Ben Naphtali tradition the expression is vocalized as

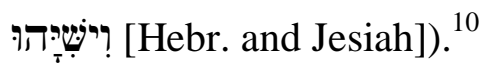

BHS: כן לבן אשר (this is written according to Ben Asher tradition).

In the Codex L this masoretic annotation refers to the Ben Naphtali tradition and mentions a vocalization variant between the Ben Asher tradition and the Ben Naphtali tradition. However, the same note in the $B H S$ is different and only mentions the Ben Asher tradition, but ignores the Ben Naphtali tradition. In the text of the $B H S$ is found the Ben Asher lecture, but, would be very important inform about the Ben Naphtali lecture as seen in the Masorah of the Codex L. Nevertheless, in the $B H K$ the same annotation is reproduced in almost identical form:

BHK: בן נפתלי ?ִישיהו (according to Ben Naphtali tradition the expression is vocalized as

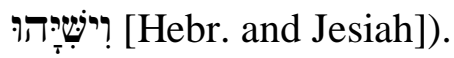

1 Chronicles 27:26: annotation in the masora parva to the verbal expression עשי (Hebr. them that did).

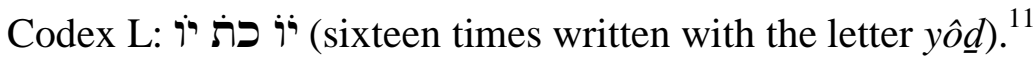

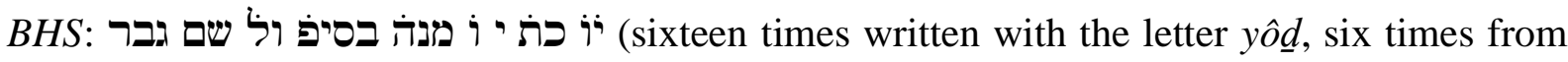
them appears in this book [i.e. in the 1 Chronicles], and once is a male name).

In the Codex L the masoretic note יi⿱

(Hebr. them that did). At the same verse the masoretic annotation לשום נבר refers to the male name פִּלוּב (Hebr. Chelub). In the BHS there is an incorrect junction of two different

${ }^{10}$ GINSBURG, 1971, vol. 1, letter $\pi$, § 617, p. 590.

${ }^{11}$ Exod 35:35; Isa 19:10; Mal 3:15; Ps 103:20; 103:21; 107:23; Prov 12:22; Esth 3:9; 9:3; Neh 13:10; 1 Chr 22:15; 27:26; 2 Chr 24:13; 26:13; 34:10; 34:17. GINSBURG, 1971, vol. 2, letter ע, § 866, p. 424; FRENSDORFF, 1968, p. 149; WEIL, 2001, § 627, p. 75; EVEN-SHOSHAN, 1997, p. 922. 


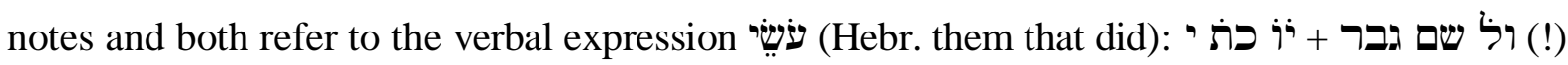
(plus i מנה בסיפ). Possibly, happened confused interpretation: in the Codex L both the notes are writing in a vertical form and both are almost jointed, as one note:

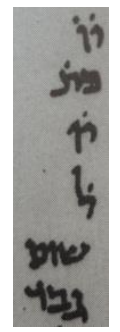

The correct situation is: the note

(Hebr. them that did) and the note פִלְ:ב (Hebr. Chelub). Yet, in the $B H K$ the two masoretic annotations are reproduced correctly in almost identical forms and refer to the verbal expression and to the male name:

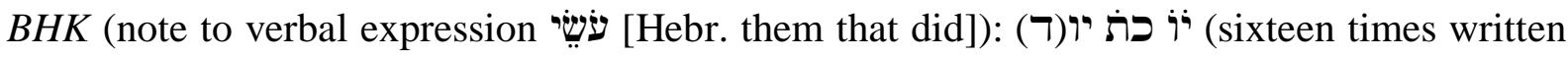
with the letter $y \hat{o}[\underline{d}])$.

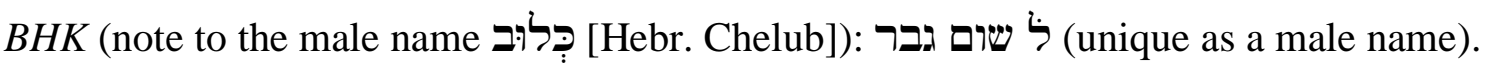

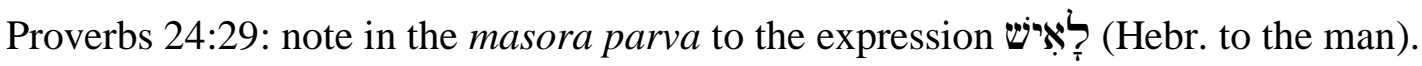

Codex L: לְָ וֹ וחד ולאיש (thirty-two times vocalized with the vocalic signal qāmēs, and once

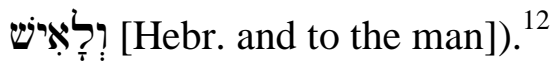

BHS: לخذ (thirty-two times).

In the Codex L the masoretic annotation has more information: the note refers to the quantity, to the vocalic signal qāmeș (⿶) and also refers to the same expression with the con-

${ }^{12}$ Gen 43:6; 43:11; 45:22; Lev 17:4; 25:27; Num 5:8; Deut 22:16; 25:9; Judg 16:19; 1 Sam 2:15; 9:7; 17:26; 17:27; 26:23; 2 Sam 12:4; 18:11; 1 Kgs 8:39; 2 Kgs 22:15; Jer 26:11; 26:16; Mal 2:12; Job 2:4; Prov 15:23; 20:3; 20:17; 24:29; Ruth 3:3; Esth 6:9; 6:11; Dan 12:6; 2 Chr 6:20; 34:23 and Jdg 19:24. GINSBURG, 1971, vol. 1, letter $\aleph$, $\S 440$, p. 51; WEIL, 2001, § 319, p. 38-39; EVEN-SHOSHAN, 1997, p. 52-53. 
junction $w \bar{a} w$ (?). In the $B H S$ the same note is short and only refers to the quantity. The same masoretic note is found in the $B H K$ too, but is almost uncleanliness:

BHK: לְָ (thirty-two times vocalized with the vocalic signal qāmēș, and once רִלְ:אִישׁ [Hebr. and to the man]).

Images: Codex L and $B H S$

Codex L

BHS

Gen 24:7 (mp)

$1 \mathrm{Chr} 12: 7(\mathrm{mp})$

$1 \mathrm{Chr} 27: 26(\mathrm{mp})$

Prov 24:29 (mp)

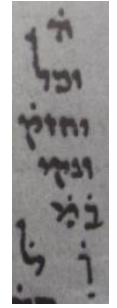

no annotation

\section{כן לבן אשר}
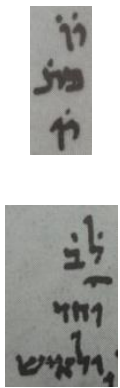

\section{Biblia Hebraica Quinta (BHQ)}

Deuteronomy 8:7: note in the masora magna to the word și (Hebr. water) vocalized with the

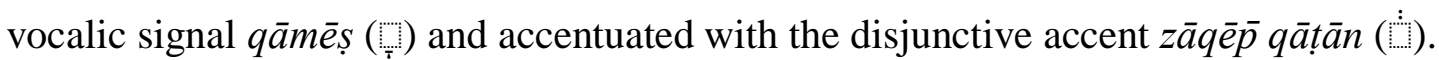

Codex L: :0:מדברה דגיהים (.... ([... the wilderness of Gehinnom). ${ }^{13}$

BHQ: : מדברה דגיהם:0) (.... ([... the wilderness of Gehinnom).

$\overline{13}$ WEIL, 2001, § 1097, p. 134; FRENSDORFF, 1972, § 13, p. 174 (additional list); MARCUS, 2013, p. 48. 
In the Codex $\mathrm{L}$ and in the $B H Q$ (fascicle 5: Deuteronomy) the masoretic annotation is

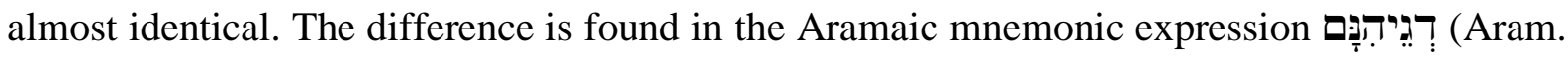

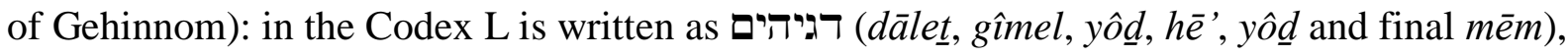
but in the $B H Q$ is written as דגיהם (dālet, gîmel, yôd $\underline{d}$, he' ' and final mēm) (in the $B H Q$ the second letter yôd is missing). The correct spelling would be דריהנם (dālet , gîmel, yôd, he', yôd and final $m \bar{e} m$ ) and it is found in the Aramaic mnemonic in the masora magna at Joel 1:20 in the Codex L and also in the BHQ (fascicle 13: The Twelve Minor Prophets).

Judges 9:18: note in the masora magna to the expression with the disjunctive accent gēršaîm ("i").

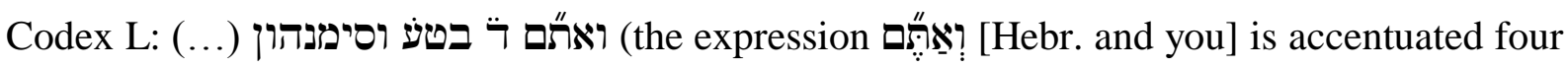
times with this accent, and their Aramaic mnemonic is $[\ldots]) .^{14}$

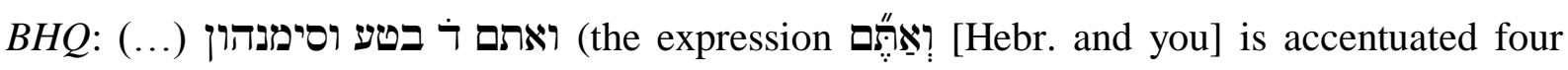
times with this accent, and their Aramaic mnemonic is [...]).

In the $B H Q$ this masoretic annotation is almost identical to its source, but there are some textual differences: in the Codex L the expression וְֶֶּ, (Hebr. and you) is written as ו"את"ם with the disjunctive accent gēršaîm ("I) above the letter tāw (ת), but in the BHQ this accent is missing. In the Codex L the masoretic term (Aram. with this cantillation accent) is abbreviated as בטע with dot above of the letter 'aîn (ע), but in the $B H Q$ the same term is abbreviated as בטע, but no dot.

\footnotetext{
${ }^{14}$ Josh 18:6; Jdg 9:18; Ezek 36:8; Neh 13:18. GINSBURG, 1971, vol. 1, letter $\boldsymbol{\aleph}$, 1485 , p. 141; FRENSDORFF, 1968, p. 230; WEIL, 2001, § 1451, p. 172; MARCUS, 2013, p. 62-63; EVEN-SHOSHAN, 1997, p. 143.
} 
Judges 14:10: note in the masora magna to the expression אָבְיהוּ (Hebr. his father).

Codex L: אתתה [רגז]ת מן ביתה מלכה (a woman [angrily rushed] from her house the $\operatorname{king}[\ldots]){ }^{15}$

BHQ: אתתה קמת מן ביתה מלכה (a woman got up from her house the king [...]).

The question is about the second term of this Aramaic mnemonic. In the $B H Q$ the second term is reproduced as קמפת (qôp, got up). However, in the Codex L this term is very difficult to be read and the letters are almost unreadable. So, is the reproduction in the $B H Q$ correct? This case is very difficult to be solved. In the Massorah

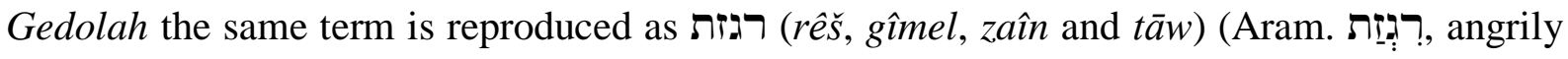
rushed). ${ }^{16}$ In the Lexicon Masoreticum the term is reproduced too as רגז, but with doubt. In this lexicon, the term is reproduced with brackets around the three first letters $\left(ת[\mathrm{\Omega}[\mathrm{I}])^{17}\right.$ When the image of the term is much increased is possible to see that the letters would be, possibly, rêš, gîmel, zaîn and tāw. The unique letter readable is the last, the letter tāa, but the three first letters are very difficult to be distinguished. This author did a comparison between this masoretic term and others masoretic terms with these same letters (rêš, gîmel, zaîn and $t \bar{a} w)$ in the Codex $\mathrm{L}$ facsimile and this author viewed with a critical eye the calligraphy by Samuel ben Jacob and the conclusion on this case is: the letters are, very probably, rêš, gîmel, zaîn and $t \bar{a} w$ and the term is, very probably, רגזות. Below the image in increase size:

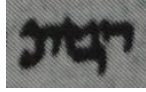

In the Codex L the same Aramaic mnemonic is found too in the masora magna at Zachariah 13:3 and in this biblical text the term is, very clear, רגוêšs, gimel, zaîn and tāw).

\footnotetext{
15 WEIL, 2001, § 1483, p. 175; MARCUS, 2013, p. 64-65.

16 WEIL, 2001, § 1483, p. 175.

17 FRANCISCO, future publication, $\S 18 \mathrm{C}$, p. 287.
} 
Hosea 11:6: note in the masora parva to the expression :

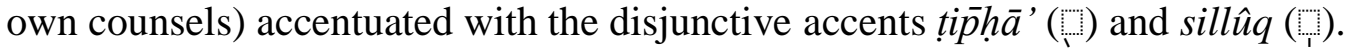

Codex L: בעט סטפ פטוֹ (twice accentuated with the disjunctive accent sôp pāsûq [i.e. sillûu $q){ }^{18}$

BHQ: ב בטע ספ כטו (twice accentuated with the disjunctive accent sôp pāsîq [i.e. sillûq]).

In the $B H Q$ this masoretic annotation is almost identical to its source, but, again, there

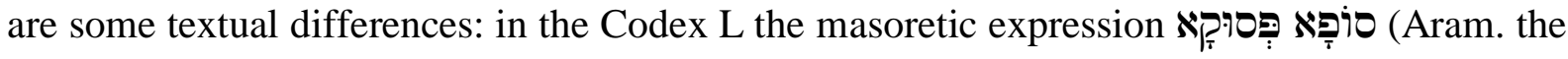
end of a verse) is abbreviated as סופ פסו בסו and in the BHQ is abbreviated as the Codex $\mathrm{L}$ the first term has the letter $w \bar{a} w(\urcorner)$, but in the $B H Q$ the same term has not it.

Qoheleth 2:12: note in the masora parva to the word (ry (Hebr. what) vocalized with the vocalic signal segôl (†).

Codex L: כֶ (twenty-four times vocalized with the vocalic signal segôl). ${ }^{19}$ BHQ: خخ (twenty-four times).

In the Codex L the masoretic annotation has more information: the note refers to the quantity and also to the vocalic signal. In the $B H Q$ the same note only refers to the quantity. Images: Codex L and $B H Q$

Codex L

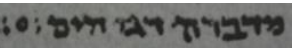

Deut 8:7 ( $\mathrm{mm})$

Judg 9:18 (mm)

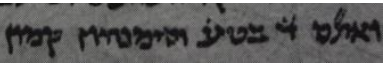

$B H Q$

\section{מדברה . דגיהם :0}

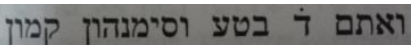

\footnotetext{
18 This masoretic annotation is incorrect and the two ocurrences refer only to the exact form of the expression: Hos 11:6; Ps 5:11. WEIL, 2001, § 3028, p. 336; EVEN-SHOSHAN, 1997, p. 632.

19 Exod 32:1; 32:23; 1 Sam 4:6; 4:14; 4:16; 15:14; 2 Sam 1:4; 1 Kgs 14:14; 2 Kgs 1:7; 4:13; 4:14; Isa 1:5; 8:9; Jer 8:9; 11:15; 16:10; Hag 1:9; Ps 4:3; 10:13; Job 7:21; Prov 31:2; Qoh 2:12; 2:22; 7:10; Lam 5:1. WEIL, 2001, § 592, p. 71-72; EVEN-SHOSHAN, 1997, p. 626.
} 
Judg 14:10 ( $\mathrm{mm})$

Hos 11:6 (mp)

Qoh 2:12 (mp)

\section{Massorah Gedolah iuxta Codicem Leningradensem B19a}

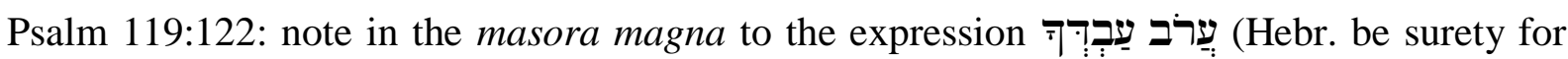
your servant).

Codex L: (.... (.... (... and the faith, allusion, to do, the words $[\ldots])$.

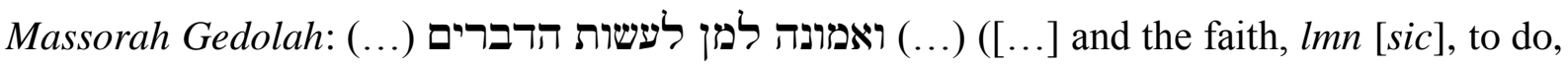
the words $[\ldots]) .^{20}$

The question is about a term in the masora magna at Psalm 119:122. In the Massorah Gedolah the term is reproduced as למן (lāmed, mēm and final nûn) (sic) (meaning?). ${ }^{21}$ However, in the Codex L is found the term רפּר (rêš, mèm and zaîn) (Hebr. allusion). This term is found in the Aleppo Codex (A) and also in the Miqra'ot Gedolot by Jacob ben Hayyim in the masora magna at the same biblical text. There is a possible explanation about this mistake: the top of the letter $r e ̂ s ̌(\neg)$ is almost stuck to the base of the letter final $k \bar{a} \bar{p}(ך)$ of the

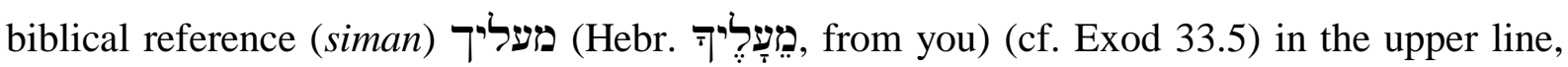
looking like the letter lāmed (ל); the letter mēm (מ) does not present problems and the letter zaîn (i) was confused with the letter final nûn (†). Below the image in increase size:

\footnotetext{
${ }^{20}$ WEIL, 2001, § 3414, p. 374.

${ }^{21}$ WEIL, 2001, § 3414, p. 374.
} 


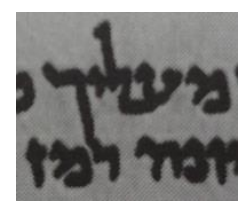

So, the correct writing is the term רמז (rês, mèm and zaîn) and this interpretation is supported by the Codex A and also by the Miqra'ot Gedolot.

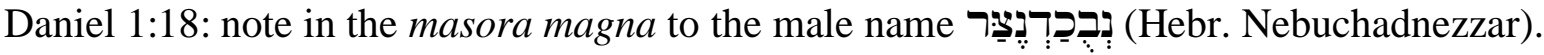

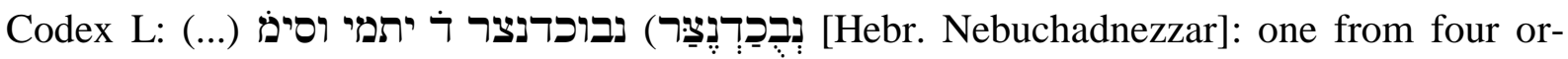
phans and their biblical references are $[\ldots]) .^{22}$

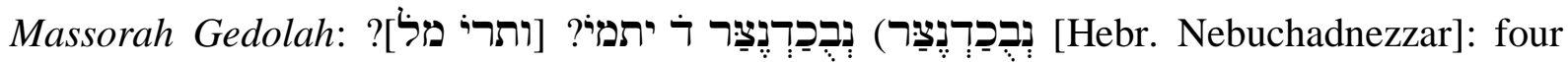
ytmy? [sic] [and two words]?).

The question is about the third term of the masoretic annotation. In the Massorah Gedolah the term is reproduced with hesitation as יתמי? [ותרי מל] (ytmy? [sic] [and two

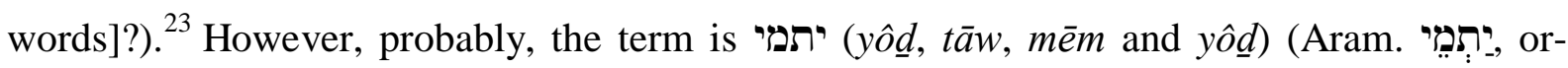
phans). There is an explanation and also a justification about this case: the male name

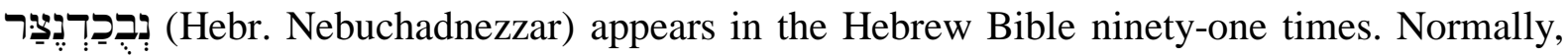
this male name appears together with others words and expressions in the middle of a verse,

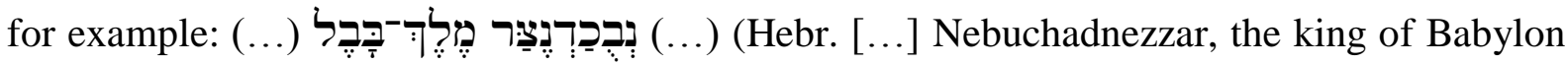

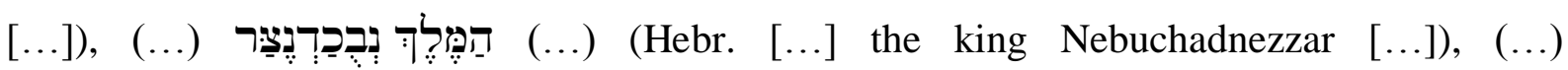

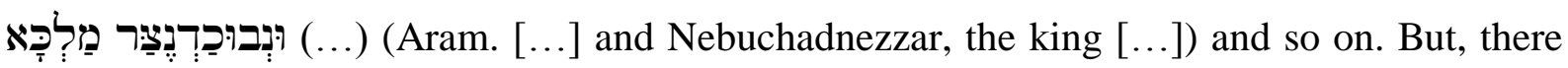
are only four texts which this male name appears quite alone and at the end of a verse, for

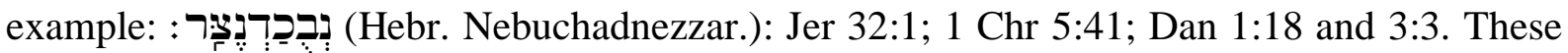
only four times are ביָתמִִ (Aram. orphans). This masoretic term of Aramaic origin belongs to

\footnotetext{
${ }^{22}$ Jer 32:1; 1 Chr 5:41; Dan 1:18; 3:3. WEIL, 2001, § 3788, p. 410; EVEN-SHOSHAN, 1997, p. 732.

${ }^{23}$ WEIL, 2001, § 3788, p. 410.
} 
the Jewish Babylonian Aramaic and it is registered by Marcus Jastrow and also by Michael Sokoloff. ${ }^{24}$ A few years ago this author sent this explanation to David Marcus ${ }^{25}$ and it will be in the future fascicle of Daniel of the $B H Q$.

Ezra 2:64: note in the masora magna to the expression פְִּ (Hebr. as one).

Codex L: דיבא וכל קהלא אידכון קמון (Aram. the wolf and all the congregation were purified, rose up [...]).

Massorah Gedolah: דיבא וכל קהלאאי דכין קמון (Aram. the wolf and all qhl'y dkyn $[$ sic $]$, rose up $[\ldots])$.

The question is about the third and fourth terms of this Aramaic mnemonic. In the

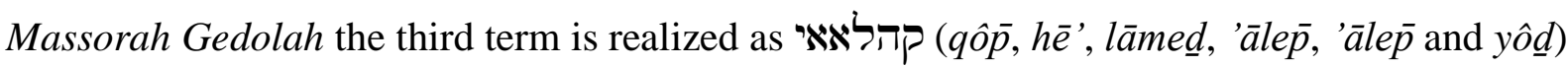
(sic) (meaning?) and the fourth term is reproduced as דכין (dāleț, kāp,$y \hat{o} \underline{d}$ and final nûn) (sic)

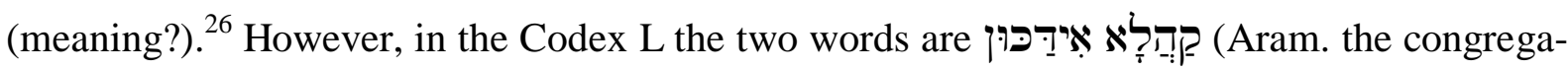
tion were purified). There is a possible explanation about this mistake: the two first letters of the term final four letters of the term almost separated. In this situation happened an incorrect separation of words and without meaning.

Images: Codex L and Massorah Gedolah

Codex L

Ps 119:122 (mm)
Massorah Gedolah

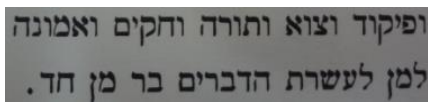

\footnotetext{
24 JASTROW, 2005, p. 604; SOKOLOFF, 2002, p. 548.

25 Professor of Bible, Ancient Semitics and Masorah at the Jewish Theological Seminary (JTS) and editor of Ezra-Nehemiah fascicle of the BHQ (Stuttgart, 2006).

${ }^{26}$ WEIL, 2001, § 3888, p. 422.
} 
Dan 1:18 (mm)

Ezra 2:64 (mm)

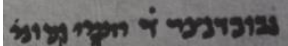

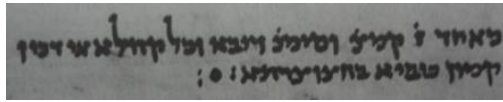

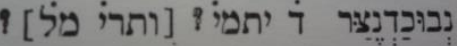

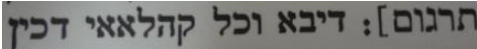

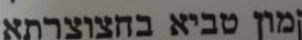

\section{General remarks about the inaccuracies and the differences}

There are situations of inaccuracies in the $B H K$ and also in the $B H S$, and there are incorrect notes in the both editions. However, occasionally there are situations of any correct annotation in the $B H K$, but the same annotation is incorrect in the $B H S$ and vice versa. In the $B H K$ some notes are not found and in the $B H S$ several notes are modified. In some cases, probably, Paul E. Kahle (1875-1965) (the Masorah editor to the $B H K$ ) and Gérard E. Weil (1926-1986) (the Masorah editor to the $B H S$ ) did not understand some masoretic annotations when they prepared the $B H K$ and the $B H S$. In some situations, the mistakes are simple confusion of letters or unreliable transcriptions of abbreviations. This author would like to know why the situations of omission in the $B H K$ and in the $B H S$. But, unfortunately, he don't has any answer. The editors have forgotten some masoretic notes? In reprints of both editions this situation has not been corrected.

There are few differences between the $B H Q$ and the Codex $\mathrm{L}$ and this edition reproduces very accurateness its source and the realization is very suitable. This edition shows important progress in the realization of masoretic annotations from Codex L to the Biblia Hebraica series. Occasionally there are some inaccuracies in transcriptions. Almost all the cases the inaccuracies are simple and generally are related to the transcriptions of terms, expressions, letters and dots. In 2012, this author prepared a extensive list ("Corrections, Suggestions and Observations to the Biblia Hebraica Quinta") with corrections, suggestions and observations on the six published fascicles until today of the $B H Q$ (from Megilloth [2004] to Judges [2011]) and this author sent it to the Deutsche Bibelgesellschaft and also to the president of 
the editorial committee, Adrian Schenker. That this list be useful to them one day in the future, when this edition be concluded.

There are in the Massorah Gedolah several mistakes in transcriptions of letters, terms and notes. Sometimes, is possibly that Weil did not understand some annotations. Maybe, the microfilm prepared by Russian National Library of Saint Petersburg (former Leningrad Saltykov-Shchedrin State Public Library), in Russia was not so fine and sometimes was difficult to read the masoretic annotations from microfilm. But this is simply conjecture. In the reprint of this publication made some years ago cases of mistakes were not corrected.

This briefly lecture emphasizes that it is important that the terms, expressions and annotations of the Masorah of the Codex L should be realized correctly, for two important reasons: 1 . to be an important testimony of the ample activity of the masoretes, as seen in the Codex $\mathrm{L}$ and 2. the usefulness of the Masorah for modern biblical research. That the $B H Q$, the new edition of the Biblia Hebraica series, based on Codex L, can be an important and reliable academic reference for future generations of scholars of the Masorah.

\section{Bibliographic References}

BEIT-ARIÉ, Malachi; SIRAT, Colette; GLATZER, Mordechai. Codices hebraicis litteris exarati quo tempore scripti fuerint exhibentes, tome I: Jusqu'à 1020. Monumenta Palaeographica Medii Aevi, Series hebraica, vol. I. Turnhout: Brepols, 1997. (in Hebrew and French)

BEN ḤAYYIM, Jacob (ed.). Biblia Rabbinica, seu Biblia Hebraica cum utraque Masora in omnes S.S. libros, Targum Onkelosi in Pentateuchum, Hierosolymitano in eundem, Jonathanis in omnes Prophetas, R. Joseph Coeci et aliorum in Psalmos, Proverbia, Job, Meghilloth, et altero Targum in Volumen Esther. Item cum commentariis Rab- 
binorum, etc. 4 vols. Venetiis, 1524-1525. (facsimile edition available on-line by National Library of Israel: http://jnul.huji.ac.il/).

DUKAN, Michèle. La Bible hébrä̈que. Les codices copiés en Orient et dans la zone séfarade avant 1280. Bibliologia, Elementa ad librorum studia pertinentia 22. Turnhout: Brepols, 2006.

ELLIGER, Karl; RUDOLPH, Wilhelm (eds.). Biblia Hebraica Stuttgartensia. 5. ed. Stuttgart: Deutsche Bibelgesellschaft, 1997.

EVEN-SHOSHAN, Abraham (ed.). A New Concordance of the Old Testament: Using the Hebrew and Aramaic Text). 2. ed. Grand Rapids: Baker, 1997. (in Hebrew)

FRANCISCO, Edson de F. Lexicon Masoreticum: Léxico de Terminologia Massorética Tiberiense (post-doctorate research, future publication).

FREEDMAN, David N. et alii (eds.). The Leningrad Codex: A Facsimile Edition. Grand Rapids-Cambridge-Leiden-New York-Köln: Eerdmans-Brill, 1998.

FRENSDORFF, Salomon. Die Massora Magna. Erster Theil: Massoretisches Wörterbuch oder die Massora in alphabetischer Ordnung. New York: KTAV, 1968. . Das Buch Ochlah W'ochlah (Massora), Herausgegeben, übersetzt und mit erläuternden Anmerkungen versehen nach einer, soweit bekannt, einzigen, in der Kaiserlichen Bibliothek zu Paris befindlichen Handschrift. New York: KTAV, 1972.

GINSBURG, Christian D. The Massorah Compiled from Manuscripts Alphabetically and Lexically Arranged. 4 vols. Jerusalem: Makor Press, 1971.

GOSHEN-GOTTSTEIN, Moshe H. (ed.). The Aleppo Codex: Provided with Massoretic Notes and Pointed by Aaron ben Asher - The Codex Considered Authoritative by Maimonides. Part One: Plates. Hebrew University Bible Project. Jerusalem: Magnes Press, 1976. 
JASTROW, Marcus (ed.). A Dictionary of the Targumim, the Talmud Babli and Yerushalmi and the Midrashic Literature. vols. 1 e 2. Peabody: Hendrickson, 2005.

KITTEL, Rudolf; KAHLE, Paul E. (eds.). Biblia Hebraica. 16. ed. Stuttgart: Württembergische Bibelanstalt, 1973.

MARCUS, David. Scribal Wit: Aramaic Mnemonics in the Leningrad Codex. Text and Studies 10. Piscataway: Gorgias Press, 2013.

SCHENKER, Adrian et alii (eds.). Biblia Hebraica Quinta. Fascicle 18: General Introduction and Megilloth. Stuttgart: Deutsche Bibelgesellschaft, 2004. (edition prepared by Jan de Waard, Piet B. Dirksen, Yohanan A. P. Goldman, Rolf Schäfer and Magne Sæbø) . (eds.). Biblia Hebraica Quinta. Fascicle 20: Ezra and Nehemiah. Stuttgart: Deutsche Bibelgesellschaft, 2006. (edition prepared by David Marcus)

. (eds.). Biblia Hebraica Quinta. Fascicle 5: Deuteronomy. Stuttgart: Deutsche Bibelgesellschaft, 2007. (edition prepared by Carmel McCarthy)

- (eds.). Biblia Hebraica Quinta. Fascicle 17: Proverbs. Stuttgart: Deutsche Bibelgesellschaft, 2008. (edition prepared by Jan de Waard) . (eds.). Biblia Hebraica Quinta. Fascicle 13: The Twelve Prophets. Stuttgart: Deutsche Bibelgesellschaft, 2010. (edition prepared by Anthony Gelston) . (eds.). Biblia Hebraica Quinta. Fascicle 7: Judges. Stuttgart: Deutsche Bibelgesellschaft, 2011. (edition prepared by Natalio Fernández Marcos)

SIRAT, Colette. Hebrew Manuscripts of the Middle Ages. Cambridge-New York-MelbourneMadrid-Cape Town-Singapore-São Paulo-Delhi: Cambridge University Press, 2002.

SOKOLOFF, Michael (ed.). A Dictionary of Jewish Babylonian Aramaic of the Talmud and Geonic Periods. Ramat-Gan-Baltimore-London: Bar Ilan University Press The John Hopkins University Press, 2002. 
WEIL, Gérard E. (ed.). Massorah Gedolah iuxta Codicem Leningradensem B19a. vol. 1 Catalogi. 2. ed. Roma: Pontificium Institutum Biblicum, 2001. 